\title{
Research on sportswear buying behavior of university students
}

\author{
Ziynet Öndoğan ${ }^{1 a}$, Arzu Şen Kılıç ${ }^{2}$, Serkan Boz ${ }^{3}$, Derya Tama ${ }^{1}$, Berna Cüreklibatır Encan ${ }^{3}$, \\ Özlem Kurtoğlu Necef ${ }^{3}$ \\ ${ }^{1}$ Ege University Textile Engineering Dept., Bornova, İzmir, 35100, Turkey \\ ${ }^{2}$ Ege University Bayındır Vocational Training School, Bayındır, İzmir, 35840, Turkey \\ ${ }^{3}$ Ege University Emel Akın Vocational Training School, Bornova, İzmir, 35100, Turkey
}

\begin{abstract}
Sport is a necessary element for maintaining life in a healthier and more balanced way. There has been a rising trend of wearing sportswear in daily life besides sports. Developments in technology have raised expectations from sportswear. Individuals expect not only durability, design and being fashionable, but also demand performance and clothing comfort. This study aims to investigate university students' awareness while buying sportswear. Professional sportsmen from Physical Education and Sports School students and Textile Engineering students having technical knowledge about clothes are included in this study. 100 students from each group were interviewed face to face. Results showed that Textile Engineering students pay more attention to technical characteristics due to their knowledge, however, aesthetic properties are revealed to be another important factor affecting buying decision. Buying decision of Physical Education and Sports School students is expected to be positively affected if they are given a seminar about raw material properties.
\end{abstract}

Keywords. Sports; sportswear; clothing comfort; buying behaviour.

\section{Introduction}

Individuals' need to be covered has been easily fulfilled for several years as ready-to-wear has become widespread, however, due to the developments in technology various benefits besides covering function is expected from clothes and different wardrobes for different parts of life such as work, sports and daily wear are required.

People living in cities have been drawn to exercise to handle stress but without getting away from the city. It is known that lately, exercising provides status and contributes to one's public image which is an important element in social life. There has been a rising

\footnotetext{
${ }^{a}$ Corresponding author: ziynet.ondogan@ege.edu.tr
} 
trend of wearing sportswear in daily life besides sports. Thus, target group of sportswear companies has expanded from people working out to an additional group who are young and following trends.

Nowadays, sports are a necessary element for maintaining life in a healthier and more balanced way. It is accepted that sports prepare individuals psychologically for daily life together with cultural activities [2].

Developments in technology and escalating standards of life have raised expectations from sportswear. Individuals expect not only durability, design and being fashionable, but also demand performance and clothing comfort [1].

In textile industry, active sportswear's market has grown globally. Competition in this sector compels manufacturers to fulfill consumers' demands of clothing comfort besides aesthetics, therefore, clothing comfort of sportswear researches have become more important [3].

Clothing comfort is related to raising standards of life, thus researches on this subject has drawn attention of both researchers and manufacturers [5]. Clothing comfort is defined by Slater (1985) as "a pleasant state of physiological, psychological and physical harmony between a human being and the environment" [4].

Characteristics that are expected from sportswear are stated on below according to the researches on clothing comfort:

- Efficiently moving away sweat from the skin,

- Quick drying,

- Breathability,

- Balancing body heat by moving away moisture and ventilating body's critical heat areas,

- Not charging electrostatically,

- Having high strength and abrasion resistance,

- Not limiting body movements,

- Being soft and durable,

- Stitches not causing discomfort,

- Having a good handle,

- Having an aesthetic appearance,

- Improving mental motivation,

- Providing easy care,

- Occupying a small place and being light, for both wearing while working out and carrying around.

In this study, it was aimed to assess university students' awareness while making buying decisions for casual and active sportswear. In literature, sportswear is divided into three subgroups as casual sportswear, professional sportswear and sportswear for hobby and health purposes [3]. These groups were taken into consideration while determining the sample group.

\section{Material and method}

This research was conducted in Ege University which is considered to have a homogeneous structure in terms of students. Professional sportsmen from Physical Education and Sports School students and Textile Engineering students having technical knowledge about clothes are included in this study. 100 students from each group were interviewed face to face on university campus. A preliminary examination showed that 183 surveys are viable.

The survey used in the study consists of 13 questions and 2 parts. First part includes 7 questions of demographics and the second part includes 6 questions about students' buying 
behaviors of daily and active sportswear. Likert type scale was used in the survey to ease expressing different opinions.

Results were evaluated by using PASW Statistics 18. Mean value, frequency, percentage, chi2 test, analysis of variance (ANOVA) and t-test were used in evaluation.

\section{Results and discussion}

Regarding to the obtained data, $51,4 \%$ of participants are studying in Textile Engineering, while $48,6 \%$ of them studying in Physical Education and Sports School at University (Table $1)$.

Table 1. Distributions of university students participating in the survey by their departments

\begin{tabular}{lccc}
\hline Department & Frequency & Percent & Valid \\
& & & Percent \\
\hline Textile Engineering & 94 & 51,4 & 51,4 \\
Physical Education and Sports School & 89 & 48,6 & 48,6 \\
\hline
\end{tabular}

The women participants' average age was 22 , height $168,6 \mathrm{~cm}$ and weight $57,7 \mathrm{~kg}$. The men participants' average age was 23 , height $179,2 \mathrm{~cm}$ and weight $77,8 \mathrm{~kg}$ (Table 2).

Table 2. The averages of age, weight and height of participant female and male university students

\begin{tabular}{llcll}
\hline Gender & Age/ Height/ Weight & $\mathrm{N}$ & Average & $\begin{array}{l}\text { Standard } \\
\text { Deviation }\end{array}$ \\
\hline Woman & Age & 88 & 22 & 1,347 \\
& Height $(\mathrm{cm})$ & 86 & 167,57 & 6,44 \\
& Weight $(\mathrm{kg})$ & 86 & 57,69 & 8,182 \\
\multirow{3}{*}{ Man } & Age & 95 & 23 & 2,167 \\
& Height $(\mathrm{cm})$ & 95 & 179,18 & 6,793 \\
& Weight $(\mathrm{kg})$ & 93 & 77,81 & 11,893 \\
\hline
\end{tabular}

When the distribution of university students participating in the survey by their demographics were analyzed, it was obtained that, $48,1 \%$ of participants are women and $51,9 \%$ of participants are men. 58,5\% of university students had been lived in Metropolitan before their university life. When the monthly average spending for wear was evaluated, it was obtained that, $27,3 \%$ of participants spend $251-500$ Turkish Liras, $24 \%$ of participants spend 501 to 750 Turkish Liras and 16,4\% of participants spend 751 to 1000 Turkish Liras (Table 3). 
Table 3. Distribution of university students participating in the survey by their demographics

\begin{tabular}{|c|c|c|c|c|}
\hline & & Frequency & Percent & $\begin{array}{l}\text { Valid } \\
\text { Percent }\end{array}$ \\
\hline \multirow[t]{3}{*}{ Gender } & Woman & 88 & 48,1 & 48,1 \\
\hline & Man & 95 & 51,9 & 51,9 \\
\hline & Missing & 0 & 0 & - \\
\hline \multirow[t]{7}{*}{ Habitat Before University } & Village & 2 & 1,1 & 1,1 \\
\hline & Town & 3 & 1,6 & 1,6 \\
\hline & County & 34 & 18,6 & 18,6 \\
\hline & City & 37 & 20,2 & 20,2 \\
\hline & Metropolitan & 107 & 58,5 & 58,5 \\
\hline & Abroad & 0 & 0 & 0 \\
\hline & Missing & 0 & 0 & - \\
\hline \multirow[t]{10}{*}{ Monthly Average Spending for Wear } & $0-250 \mathrm{TL}$ & 18 & 9,8 & 9,8 \\
\hline & $251-500 \mathrm{TL}$ & 50 & 27,3 & 27,3 \\
\hline & $501-750 \mathrm{TL}$ & 44 & 24 & 24 \\
\hline & $751-1000 \mathrm{TL}$ & 30 & 16,4 & 16,4 \\
\hline & $\begin{array}{l}1001-1250 \\
\text { TL }\end{array}$ & 15 & 8,2 & 8,2 \\
\hline & $1251-1500 \mathrm{TL}$ & 10 & 5,5 & 5,5 \\
\hline & $1501-1750 \mathrm{TL}$ & 7 & 3,8 & 3,8 \\
\hline & $\begin{array}{l}1751-2000 \\
\text { TL }\end{array}$ & 4 & 2,2 & 2,2 \\
\hline & $\begin{array}{l}2001 \mathrm{TL} \text { and } \\
\text { more }\end{array}$ & 5 & 2,7 & 2,7 \\
\hline & Missing & 0 & 0 & - \\
\hline
\end{tabular}

The distribution of monthly average spending for casual (Table 4) and active (Table 5) sportswear of participant female and male students were analyzed, it can be said that in casual sportswear, men spend less money than women. It is opposite in active sportswear; men spend more money than women in active sportswear.

Table 4. Distribution of monthly average spending for casual sportswear of participant female and male students

\begin{tabular}{|c|c|c|c|c|c|c|c|c|}
\hline & & \multicolumn{6}{|c|}{ Monthly Average Spending for Casual Sports Wear } & \multirow[t]{4}{*}{ Total } \\
\hline & & 100 & $101-$ & $201-$ & $301-$ & $401-$ & 501 & \\
\hline & & $\mathrm{TL}$ & 200 & 300 & 400 & 500 & $\mathrm{TL}$ & \\
\hline & & $\begin{array}{l}\text { and } \\
\text { less }\end{array}$ & $\mathrm{TL}$ & $\mathrm{TL}$ & $\mathrm{TL}$ & $\mathrm{TL}$ & $\begin{array}{l}\text { and } \\
\text { more }\end{array}$ & \\
\hline \multirow[t]{2}{*}{ Gender } & Woman & 52 & 22 & 11 & 1 & 1 & 0 & 87 \\
\hline & Man & 60 & 16 & 12 & 3 & 3 & 1 & 95 \\
\hline Total & & 112 & 38 & 23 & 4 & 4 & 1 & 182 \\
\hline
\end{tabular}


Table 5. Distribution of monthly average spending for active sportswear of participant female and male students

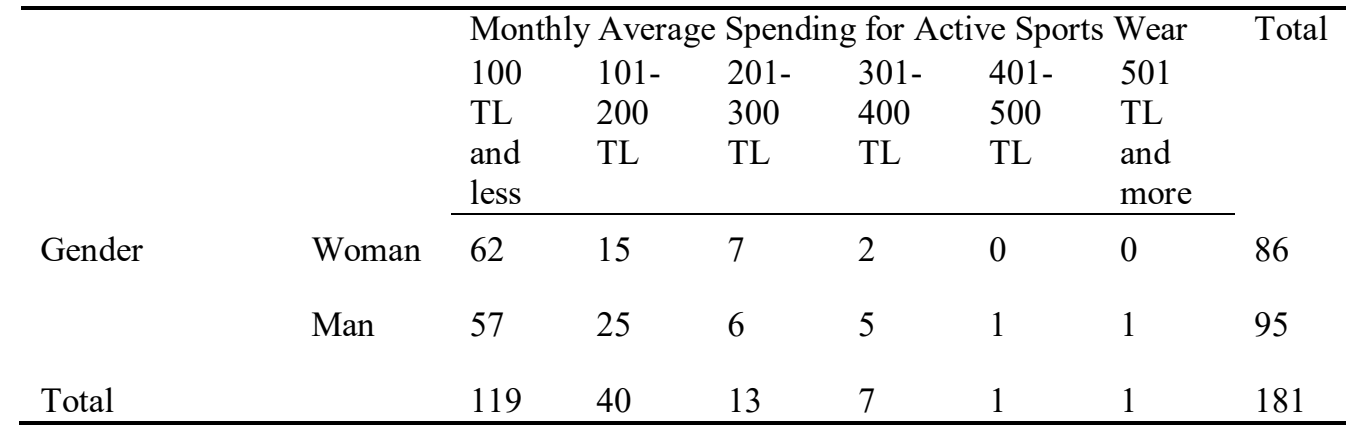

A significant correlation was not detected between monthly spending average for casual sportswear and the gender of the participating students $(\chi=4,219 ; \mathrm{df}=5 ; \mathrm{p}=0,518)$. Also a significant correlation was not detected between monthly spending average for active sportswear and the gender of the participating students $(\chi=5,639 ; \mathrm{df}=5 ; \mathrm{p}=0,343)$. A significant correlation was not detected between monthly spending average for casual sportswear and the study departments of the participating students $(\chi=10,115 ; \mathrm{df}=5$; $\mathrm{p}=0,072$ ). However, A significant correlation was detected between monthly spending average for active sportswear and the study departments of the participating students $(\chi=26,432 ; \mathrm{df}=5 ; \mathrm{p}=0,00)$.

Table 6. Distribution of factors affecting sportswear buying decision of university students

\begin{tabular}{llll}
\hline & $\mathrm{N}$ & Average & $\begin{array}{l}\text { Standard } \\
\text { Deviation }\end{array}$ \\
\hline Fitting & & & 0,442 \\
Comfort & 178 & 1,24 & 0,577 \\
Color & 179 & 1,32 & 0,531 \\
Design/ Model & 179 & 1,38 & 0,562 \\
Quality & 180 & 1,38 & 0,628 \\
Fabric Properties & 180 & 1,45 & 0,692 \\
Figure & 181 & 1,67 & 0,795 \\
Price & 178 & 1,69 & 0,777 \\
Raw Material (Fiber) Properties & 180 & 1,69 & 0,977 \\
Brand & 178 & 2,15 & 1,369 \\
Sewing properties & 180 & 2,27 & 1,072 \\
Accessory properties & 179 & 2,35 & 1,052 \\
Fashion & 179 & 2,4 & 1,28 \\
Advertisement/ Promotion & 179 & 2,83 & 1,193 \\
\end{tabular}

14 different statements, regarding the factors affecting the sportswear buying decision, are given to the participant university students and they were asked to mark the significance of these statements (Table 6). In the five-point Likert scale, "Very important" 1, "Important" 2, "Moderately important" 3, "Somewhat important" 4 and "Does not matter" were coded as 5 . When the factors, which affect the sportswear buying decision of university students, were analyzed, it's observed that fitting and comfort factors take first 
places. Also the color, design and model factors are significant for buying decision. The review also showed that advertising and promotional efforts are less important factors affecting the sportswear buying decision of students.

When the casual sportswear usage of participant students was evaluated; $82 \%$ of students wear T-shirts very often casually. $29 \%$ of students prefer to wear shorts very often and $43 \%$ prefer often. $41 \%$ of students use sport trousers very often and $32 \%$ use sport trousers often casually.

When the active sportswear usage of participant students was evaluated; $74 \%$ of students prefer to wear t-shirts very often, $23 \%$ of students prefer to wear t-shirts often during active sport life. $44 \%$ of students use shorts very often, $36 \%$ of student use shorts often during active sport life. The sport trousers which are preferred casually are used $18 \%$ very often, $22 \%$ often and $40 \%$ rarely by university students during active sport.

Table 7. The differences between the garment buying decision of university students and their monthly average spending for casual sportswear

\begin{tabular}{|c|c|c|c|c|c|c|c|c|}
\hline & $\begin{array}{l}\text { Monthly } \\
\text { Average } \\
\text { Spending } \\
\text { for Wear }\end{array}$ & $\mathrm{N}$ & Average & $\begin{array}{l}\text { Std. } \\
\text { Deviation }\end{array}$ & $\mathrm{F}$ & $\mathrm{df1}$ & $\mathrm{df} 2$ & $p$ \\
\hline \multirow[t]{6}{*}{ Comfort } & $\begin{array}{l}100 \mathrm{TL} \text { and } \\
\text { less }\end{array}$ & 109 & 1,32 & 0,525 & 5,271 & 5 & 172 & 0.00 \\
\hline & $\begin{array}{l}101-200 \\
\text { TL }\end{array}$ & 37 & 1,35 & 0,588 & & & & \\
\hline & $\begin{array}{l}201-300 \\
\text { TL }\end{array}$ & 23 & 1,17 & 0,491 & & & & \\
\hline & $\begin{array}{l}301-400 \\
\text { TL }\end{array}$ & 4 & 1,25 & 0,5 & & & & \\
\hline & $\begin{array}{l}401-500 \\
\text { TL }\end{array}$ & 4 & 1,5 & 1 & & & & \\
\hline & $\begin{array}{l}501 \mathrm{TL} \text { and } \\
\text { more }\end{array}$ & 1 & 4 & - & & & & \\
\hline \multirow[t]{6}{*}{ Price } & $\begin{array}{l}100 \mathrm{TL} \text { and } \\
\text { less }\end{array}$ & 111 & 1,69 & 0,818 & 2,293 & 5 & 173 & 0,04 \\
\hline & $\begin{array}{l}101-200 \\
\text { TL }\end{array}$ & 37 & 1,73 & 0,652 & & & & \\
\hline & $\begin{array}{l}201-300 \\
\text { TL }\end{array}$ & 22 & 1,5 & 0,673 & & & & \\
\hline & $\begin{array}{l}301-400 \\
\text { TL }\end{array}$ & 4 & 1,5 & 0,577 & & & & \\
\hline & $\begin{array}{l}401-500 \\
\text { TL }\end{array}$ & 4 & 2 & 0,816 & & & & \\
\hline & $\begin{array}{l}501 \mathrm{TL} \text { and } \\
\text { more }\end{array}$ & 1 & 4 & - & & & & \\
\hline \multirow[t]{6}{*}{$\begin{array}{l}\text { Advertisement/ } \\
\text { Promotion }\end{array}$} & $\begin{array}{l}100 \mathrm{TL} \text { and } \\
\text { less }\end{array}$ & 108 & 3,03 & 1,131 & 2,538 & 5 & 169 & 0,03 \\
\hline & $\begin{array}{l}101-200 \\
\text { TL }\end{array}$ & 37 & 3,24 & 1,164 & & & & \\
\hline & $\begin{array}{l}201-300 \\
\text { TL }\end{array}$ & 21 & 2,52 & 1,401 & & & & \\
\hline & $\begin{array}{l}301-400 \\
\text { TL }\end{array}$ & 4 & 3,5 & 1,291 & & & & \\
\hline & $\begin{array}{l}401-500 \\
\text { TL }\end{array}$ & 4 & 4,5 & 0,577 & & & & \\
\hline & $\begin{array}{l}501 \mathrm{TL} \text { and } \\
\text { more }\end{array}$ & 1 & 4 & - & & & & \\
\hline
\end{tabular}


When the differences between the garment buying decision of university students and their monthly average spending for casual (Table 7) and active (Table 8) sportswear were evaluated. It was determined that, there is a statistical significant relationship between their monthly average spending for wear and comfort, price and advertisement/ promotion factors for casual sportswear. It has also obtained that, there is a statistical significant relationship between their monthly average spending for wear and comfort and brand factors.

Table 8. The differences between the garment buying decision of university students and their monthly average spending for active sportswear.

\begin{tabular}{|c|c|c|c|c|c|c|c|c|}
\hline & $\begin{array}{l}\text { Monthly } \\
\text { Average } \\
\text { Spending for } \\
\text { Wear }\end{array}$ & $\mathrm{N}$ & Average & $\begin{array}{l}\text { Std. } \\
\text { Deviation }\end{array}$ & $\mathrm{F}$ & df1 & df2 & $\mathrm{p}$ \\
\hline \multirow[t]{6}{*}{ Comfort } & $100 \mathrm{TL}$ and less & 117 & 1,37 & 0,551 & 6,461 & 5 & 171 & 0.00 \\
\hline & $101-200 \mathrm{TL}$ & 38 & 1,16 & 0,437 & & & & \\
\hline & $201-300 \mathrm{TL}$ & 13 & 1,38 & 0,768 & & & & \\
\hline & $301-400 \mathrm{TL}$ & 7 & 1 & 0 & & & & \\
\hline & $401-500 \mathrm{TL}$ & 1 & 1 & - & & & & \\
\hline & $501 \mathrm{TL}$ and more & 1 & 4 & - & & & & \\
\hline \multirow{6}{*}{ Brand } & $100 \mathrm{TL}$ and less & 118 & 2,52 & 1,495 & 2,664 & 5 & 172 & 0,04 \\
\hline & $101-200 \mathrm{TL}$ & 38 & 1,89 & 0,953 & & & & \\
\hline & $201-300 \mathrm{TL}$ & 13 & 1,92 & 1,115 & & & & \\
\hline & $301-400 \mathrm{TL}$ & 7 & 1,29 & 0,488 & & & & \\
\hline & $401-500 \mathrm{TL}$ & 1 & 1 & - & & & & \\
\hline & $501 \mathrm{TL}$ and more & 1 & 1 & - & & & & \\
\hline
\end{tabular}

Table 9. The differences between the factors affecting garment buying decision of university students and their study departments

\begin{tabular}{|c|c|c|c|c|c|c|c|}
\hline & Department & $\mathrm{N}$ & Average & $\begin{array}{l}\text { Std. } \\
\text { Deviation }\end{array}$ & $\mathrm{t}$ & $\mathrm{df}$ & $\mathrm{p}$ \\
\hline \multirow{2}{*}{ Colour } & Textile Eng. & 93 & 1,37 & 0,484 & $-0,37$ & 177 & 0,709 \\
\hline & $\begin{array}{l}\text { Physical Edu. } \\
\text { and Sports Sch. }\end{array}$ & 86 & 1,4 & 0,58 & & & \\
\hline \multirow[t]{2}{*}{ Design/Model } & Textile Eng. & 94 & 1,34 & 0,476 & $-1,07$ & 178 & 0,286 \\
\hline & $\begin{array}{l}\text { Physical Edu. } \\
\text { and Sports Sch. }\end{array}$ & 86 & 1,43 & 0,642 & & & \\
\hline \multirow[t]{2}{*}{ Figure } & Textile Eng. & 93 & 1,6 & 0,662 & $-1,57$ & 176 & 0,119 \\
\hline & $\begin{array}{l}\text { Physical Edu. } \\
\text { and Sports Sch. }\end{array}$ & 85 & 1,79 & 0,914 & & & \\
\hline \multirow[t]{2}{*}{ Fabric Properties } & Textile Eng. & 94 & 1,69 & 0,656 & 0,464 & 179 & 0,643 \\
\hline & $\begin{array}{l}\text { Physical Edu. } \\
\text { and Sports Sch. }\end{array}$ & 87 & 1,64 & 0,731 & & & \\
\hline Accessory & Textile Eng. & 94 & 2,47 & 0,991 & 0,88 & 177 & 0,38 \\
\hline Properties & $\begin{array}{l}\text { Physical Edu. } \\
\text { and Sports Sch. }\end{array}$ & 85 & 2,33 & 1,117 & & & \\
\hline \multirow[t]{2}{*}{ Sewing Properties } & Textile Eng. & 94 & 2,45 & 1,033 & 1,321 & 177 & 0,188 \\
\hline & $\begin{array}{l}\text { Physical Edu. } \\
\text { and Sports Sch. }\end{array}$ & 85 & 2,24 & 1,109 & & & \\
\hline Raw Material & Textile Eng. & 93 & 2,15 & 0,999 & $-0,02$ & 176 & 0,987 \\
\hline
\end{tabular}




\begin{tabular}{|c|c|c|c|c|c|c|c|}
\hline (Fiber) Properties & $\begin{array}{l}\text { Physical Edu. } \\
\text { and Sports Sch. }\end{array}$ & 85 & 2,15 & 0,958 & & & \\
\hline \multirow[t]{2}{*}{ Comfort } & Textile Eng. & 93 & 1,29 & 0,523 & \multirow[t]{2}{*}{$-0,02$} & \multirow[t]{2}{*}{177} & \multirow[t]{2}{*}{0,418} \\
\hline & $\begin{array}{l}\text { Physical Edu. } \\
\text { and Sports Sch. }\end{array}$ & 86 & 1,36 & 0,631 & & & \\
\hline \multirow[t]{2}{*}{ Fitting } & Textile Eng. & 93 & 1,22 & 0,413 & \multirow[t]{2}{*}{$-0,81$} & \multirow[t]{2}{*}{176} & \multirow[t]{2}{*}{0,404} \\
\hline & $\begin{array}{l}\text { Physical Edu. } \\
\text { and Sports Sch. }\end{array}$ & 85 & 1,27 & 0,473 & & & \\
\hline \multirow[t]{2}{*}{ Quality } & Textile Eng. & 94 & 1,45 & 0,58 & \multirow[t]{2}{*}{$-0,84$} & \multirow[t]{2}{*}{178} & \multirow[t]{2}{*}{0,943} \\
\hline & $\begin{array}{l}\text { Physical Edu. } \\
\text { and Sports Sch. }\end{array}$ & 86 & 1,45 & 0,68 & & & \\
\hline \multirow[t]{2}{*}{ Brand } & Textile Eng. & 94 & 2,66 & 1,583 & \multirow[t]{2}{*}{$-0,07$} & \multirow[t]{2}{*}{178} & \multirow[t]{2}{*}{0} \\
\hline & $\begin{array}{l}\text { Physical Edu. } \\
\text { and Sports Sch. }\end{array}$ & 86 & 1,85 & 0,927 & & & \\
\hline \multirow[t]{2}{*}{ Price } & Textile Eng. & 94 & 1,74 & 0,775 & \multirow[t]{2}{*}{4,143} & \multirow[t]{2}{*}{178} & \multirow[t]{2}{*}{0,366} \\
\hline & $\begin{array}{l}\text { Physical Edu. } \\
\text { and Sports Sch. }\end{array}$ & 86 & 1,64 & 0,781 & & & \\
\hline \multirow[t]{2}{*}{ Fashion } & Textile Eng. & 94 & 2,93 & 1,211 & \multirow[t]{2}{*}{0,906} & \multirow[t]{2}{*}{177} & \multirow[t]{2}{*}{0,279} \\
\hline & $\begin{array}{l}\text { Physical Edu. } \\
\text { and Sports Sch. }\end{array}$ & 85 & 2,72 & 1,351 & & & \\
\hline Advertisement/ & Textile Eng. & 92 & 3,15 & 1,068 & \multirow[t]{2}{*}{1,086} & \multirow[t]{2}{*}{174} & \multirow[t]{2}{*}{0,33} \\
\hline Promotion & $\begin{array}{l}\text { Physical Edu. } \\
\text { and Sports Sch. }\end{array}$ & 84 & 2,98 & 1,317 & & & \\
\hline
\end{tabular}

When the differences were analyzed between the factors affecting garment buying decision of university students and their study departments; it's observed that, there is only one significant difference in terms of brand factor between the departments (Table 9). The students of Physical Education and Sports School care more about the garment brand according to the Textile Engineering students.

Table 10. The factors affecting garment buying decision of university students.

\begin{tabular}{llll}
\hline & $\mathrm{N}$ & Average & $\begin{array}{l}\text { Standart } \\
\text { Deviation }\end{array}$ \\
\hline $\begin{array}{l}\text { When new fashionable garments offered for } \\
\text { sale }\end{array}$ & 75 & 2,24 & 0,803 \\
$\begin{array}{l}\text { When the used garments are worn or unable to } \\
\text { wear again }\end{array}$ & 120 & 1,79 & $0,819 \mathrm{~W}$ \\
$\begin{array}{l}\text { When the used garments are boring } \\
\begin{array}{l}\text { When I encounter with a product that I like } \\
\text { randomly }\end{array}\end{array}$ & 133 & 2,05 & 0,791 \\
Other reasons & 124 & 1,95 & 0,805 \\
\hline
\end{tabular}

When the factors, which affect garment buying decision of university students, were investigated, it is notable as the most important factor "Decide to buy a new garment when the used garments are worn or unable to wear" (Table 10). Additionally the second important factor is "'" to decide buying a new garment. Fashion is the least affective factor for Textile Engineering students as well as Physical Education and Sports School students to decide buying a new sportswear. 


\section{Conclusions and recommendations}

The results of study show that the university students behave conscious when buying new garments. When the study data evaluated it's seen that the university students care about comfort of casual wear and T-shirt has become inevitable for casual sportswear and active sportswear of university students. When the factors, which affect the sportswear buying decision of university students, were analyzed, it is observed that fitting and comfort factors take first places. Also the color, design and model factors are significant for buying decision.

Results showed that Textile Engineering students pay more attention to technical characteristics due to their knowledge, however, aesthetic properties are revealed to be another important factor affecting buying decision. Buying decision of Physical Education and Sports School students are expected to be positively affected if they were given a seminar about raw material properties.

When the data, obtained from the study results were analyzed; fashion was found the least affective factor for university students to decide buying a new sportswear. This situation occurs owing to functionality of sportswear being predominant according to its aesthetics.

\section{References}

1. Çivitci, Ş. ve Dengin, S. Koşu Giysileri Konforunun Kullanıcılar Tarafindan Değerlendirilmesi Üzerine Bir Araştırma, International Journal of Science Culture ad Sport, SI(1):553-569, 2014.

2. Dağlı Ekmekçi, Y.A., Ekmekçi, R. ve İrmiş, A. Küreselleşme ve Spor Endüstrisi, Pamukkale Journal of Sport Sciences, 4 (1): 91-117, 2013.

3. Güneşoğlu, S. Sportif Amaçlı Giysilerin Konfor Özelliklerinin Araştırılması, Doktora Tezi, Uludağ Üniversitesi Fen Bilimleri Enstitüsü, 208s., 2005.

4. Okur, A., Küçüka, S. ve Kaplan, S. Giysi termal konforunun belirlenmesine yönelik bir yöntem geliştirilmesi, TÜBİTAK, 2008.

5. Öner, E. ve Okur, A. Materyal, üretim teknolojisi ve kumaş yapısının termal konfora etkileri, Tekstil veMühendis, 17(80): 20-29, 2010. 